\title{
ПРОБЛЕМИ СЕРТИФІКАЦІЇ ПРОГРАМНОГО ЗАБЕЗПЕЧЕННЯ АВТОМАТИЗОВАНИХ СИСТЕМ КОНТРОЛЮ
}

\author{
Інститут інформатики НАУ, e-mail: raychev@zeos.net
}

\begin{abstract}
Розглянуто питання побудови процедури сертифікаиії програмного забезпечення автоматизованих систем контролю як одного з класів критичних програмних систем, для яких сертифікація відповідності є обов 'язковою. Розроблено методи формалізаџї процедури формування критерїв якості та побудовано узагальнену модель якості програмного забезпечення. Створення таких методів дає можливість підвищити ефективність і якість випробувань, а тому зменшує трудомісткість иісї операчії та збільшує достовірність результатів сертифікації відповідності.
\end{abstract}

\section{Вступ}

Автоматизовані системи контролю (АСК) базуються на вимірювальній інформації і в сукупності складають один із класів інформаційних управляючих систем . Ці автоматизовані системи характеризуються використанням програмного забезпечення (ПЗ) обробки параметричної інформації для оцінки стану об'єкта контролю.

На сьогодні особливу актуальність набуває проблема підвищення безпеки об'єктів, контрольованих за допомогою АСК. Одним зі шляхів досягнення цієї мети є поліпшення якості ПЗ АСК, що особливо важливо при експлуатації систем даного класу, оскільки ці системи є критичними, бо вони пов'язані з забезпеченням безпеки життедіяльності.

Наслідки низької якості АСК можуть бути досить серйозні, наприклад, аварії під час виконання польотів повітряних суден, катастрофи під час запуску космічних кораблів, аварії на атомних електростанціях тощо.

Наукові дослідження якості ПЗ переважно присвячені питанням побудови систем забезпечення якості при проектуванні та розробці ПЗ. Прямо застосувати отримані методи під час сертифікації не можна, тому що вони призначені для вибору найкращих проектних рішень, стилей програмування і пошуку дефектів, а при сертифікації необхідно оцінювати досягнутий рівень якості ПЗ.

\section{Постановка завдання}

Через зазначені причини сертифікаційні випробування таких систем проводяться недостатньо глибоко, часто без дотримання процедури і вимог стандартів [1-3] чи в багатьох випадках взагалі не проводяться.

Однією з головних причин такого положення $€$ відсутність сучасних науково обгрунтованих комп'ютеризованих технологій сертифікації ПЗ подібних технічних систем.

Метою роботи $\epsilon$ аналіз проблем сертифікації ПЗ АСК і створення ефективних методів та засобів побудови цільової моделі якості, застосовуваної при сертифікаційних випробуваннях.

\section{Аналіз проблем сертифікації програмного забезпечення}

Оскільки сертифікація - це процедура визначення відповідності вимогам, то, насамперед, необхідно визначити і формалізувати вимоги до ПЗ АСК. Будемо вважати, що якщо дані системи задовольняють вимоги і рекомендації основної групи стандартів якості ПЗ [1-8], то вони придатні до експлуатації. Ці системи повинні також задовольняти вимоги галузевих стандартів, наприклад, [9], нормативних документів і вимоги користувача, які можуть бути відбиті у технічному завданні (Т3) на розробку ПЗ.

У літературі недостатньо розглянуто питання, пов'язані з сертифікацією ПЗ і, особливо, з сертифікаційними випробуваннями. Тому існує спрощена думка, що процес сертифікації зводиться до простого порівняння належних або заявлених характеристик 3 фактичними властивостями програмного продукту. При цьому вважають, що ці властивості відомі. Але при такому підході випускають 3 уваги ряд важливих проблем, з яких розглянемо три.

По-перше, необхідно визначити належні показники якості ПЗ. Оскільки вимог до ПЗ існує досить багато, пропонуємо спочатку виділити зі стандартів профільні вимоги до даного класу ПЗ. Надалі потрібно систематизувати їх, визначивши набір нормативних галузевих показників якості ПЗ. Після цього можна здійснювати перевірку відповідності фактичних характеристик ПЗ нормативним показникам.

По-друге, необхідно визначити, як одержати фактичні характеристики ПЗ. Шукані фактичні показники якості ПЗ можна отримати виключно шляхом сертифікаційних випробувань. Дійсно, заявлені розробником характеристики ПЗ критичних систем не можуть братися на віру чи перевірятися за допомогою використання власної внутрішньої системи керування якістю, якщо така $\epsilon$.

По-третє, сертифікаційні випробування є трудомісткою і витратною процедурою, яка потребує залучен- 
ня експертів і побудови великої кількості тестових наборів даних, а тому необхідно ії автоматизувати.

Група стандартів, що мають відношення до якості ПЗ, складається $з$ декількох серій.

Оцінювати якість ПЗ можна відповідно до стандартів серії ISO/IEC14598 [6], що пропонують способи оцінки характеристик продукту, запозичаючи, однак, модель якості, визначення загальних вимог до ПЗ, а також критерії його оцінки з ISO/IEC 9126 [5].

Стандарти серій ISO9000 [4] і CMM [10; 11] регламентують правила створення якісного продукту шляхом введення власної системи управління якістю, правила створення якісних програмних систем, а не процедуру їхньої оцінки, а тому домінуючим є підхід до сертифікації відповідно до призначення ПЗ [12].

Вітчизняні та зарубіжні стандарти [1-3; 5; 7] рекомендують проводити сертифікацію ПЗ із залученням третьої сторони (незалежних лабораторій сертифікації), автоматизуючи процес випробувань впритул до етапу ухвалення рішення про сертифікацію відповідності, за яке цілком відповідає орган сертифікації.

Отже, підхід до сертифікації ПЗ заснований на таких положеннях:

- визначення сертифікаційних вимог до ПЗ згідно з його призначенням;

- проведення випробувань третьою стороною під керівництвом офіційної структури;

- максимальна автоматизація процесу сертифікаційних випробувань.

Випробування ПЗ грунтуються на оцінці того факту, наскільки його характеристики задовольняють моделі якості для даного класу ПЗ. Ця модель повинна бути побудована до проведення випробувань, а для визначення й оцінки показників якості необхідно розробити відповідні методи та засоби (рис. 1).

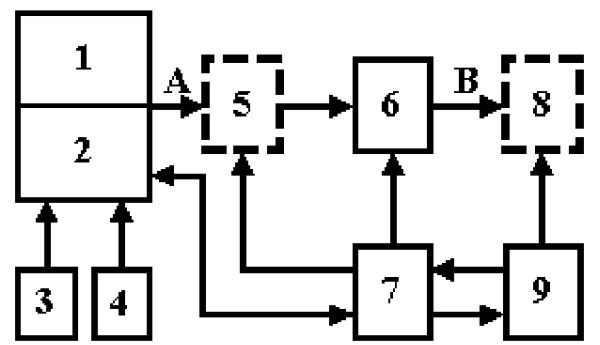

Рис. 1. Технологічна схема процедури сертифікації:

1 - аналіз стандартів і формування вимог; 2 - належні показники якості ПЗ; 3 - розробники ПЗ; 4 - замовники ПЗ; 5 - модель якості ПЗ; 6 - сертифікаційні випробування; 7 - лабораторія сертифікації; 8 - сертифікація відповідності; 9 - орган сертифікації;

$A$ - узгодження характеристик якості; $B$ - фактичні показники якості
Основною серією стандартів, що висуває загальні вимоги до ПЗ, є серія ISO/IEC 9126 [5; 7; 8]. Існує ряд вітчизняних державних стандартів, що гармонізовані зі стандартом [5], з яких базовим $\epsilon$ ДСТУ 2850-94 [2]. Модель якості П3, розроблена в серії ISO/IEC 9126 [5; 7; 8], є незалежною і загальновизнаною на сьогодні, а тому пропонується взяти іiі за основу і застосувати при сертифікаційних випробуваннях.

Вимоги і рекомендації даної серії стандартів будемо вважати загальними вимогами до якості П3, а стандарти ISO/IEC 9126, ДСТУ 2850-94 загальними стандартами якості ПЗ.

Надалі пропонується відображати вимоги галузевих стандартів і нормативних документів саме на уніфіковані показники якості загальних стандартів.

Програмне забезпечення АСК розв'язує такі задачі:

- відтворення параметричної інформації;

- контроль виходів параметрів за обмеження;

- контроль якості функціонування об'єкта.

Залежно від призначення ПЗ АСК ці задачі можуть розв'язуватися як у режимі реального часу, так і після функціонування об'єкта. Тому ПЗ систем розглянутого класу складається 3 таких базових комплексів програм:

- комплекс програм відтворення;

- комплекс програм допускового контролю;

- комплекс контролю якості функціонування об'єкта.

Отже, для оцінки рівня якості необхідно передусім побудувати модель якості.

Модель якості ПЗ АСК буде складатися з показників якості, які пропонується класифікувати згідно 3 наявними базовими програмними комплексами цих систем, що показано на рис. 2.

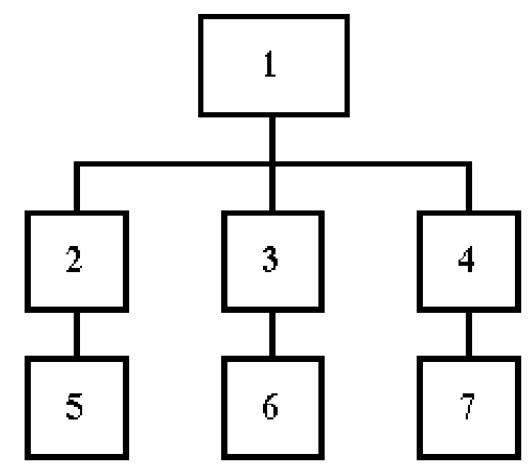

Рис. 2. Класифікація показників якості ПЗ АСК: 1 - ПЗ АСК; 2 - комплекс програм відтворення параметричної інформації; 3 - комплекс програм допускового контролю; 4 - комплекс програм контролю якості функціонування об'єкта; 5 - показники якості відтворення; 6 - показники якості виявлення небезпечних відхилень; 7 - показники якості функціонування об'єкта 
Розглядувані характеристики якості є універсальними для ПЗ даного класу інформаційних систем, бо характеризують якість основних комплексів, з яких складається ПЗ цих систем. На разі треба співвіднести галузеві показники з характеристиками якості загальних стандартів.

\section{Відображення показників якості \\ на множину характеристик \\ загальних стандартів}

3 боку користувача базові показники якості вибирають 3 галузевих стандартів і нормативних документів. 3 боку органу сертифікації, що перевіряє ці показники, і лабораторії сертифікації, що проводить сертифікаційні випробування, показники якості ПЗ повинні бути уніфікованими і вибиратися з загальних стандартів. Нарешті, розробник ПЗ може користатися власною системою оцінки якості, що може бути заснована на контролі ряду показників, а також деяких внутрішніх характеристик якості ПЗ $[10 ; 13]$.

Із зазначеного випливає необхідність розв'язання задачі відображення показників якості галузевих стандартів на множину показників якості загальних стандартів.

Семантичне відображення показників якості галузевих стандартів і нормативних документів на множину характеристик якості загальних стандартів необхідно проводити зважаючи на такі причини:

- для сертифікаційних випробувань необхідно використовувати уніфіковані показники якості, зафіксовані в загальних стандартах;

- вимоги галузевих стандартів, сформульовані в предметних термінах, не завжди зрозумілі фахівцям лабораторії сертифікації, що проводять випробування;

- система розрахунку метрик атрибутів характеристик якості більшою мірою пророблена саме в галузевих стандартах.

Стороні, яка виконує сертифікаційні випробування, зручно користатися характеристиками якості загальних стандартів, користувачам - галузевими стандартами, розробникам - показниками внутрішньої системи управління якістю ПЗ.

Як правило, вимоги до ПЗ, сформульовані замовником, не завжди відповідають технологічним критеріям, які використовує розробник. Відповідно показники якості, важливі для користувача, не погоджені з показниками якості, що використовують розробники [14].

Отже, виникає проблема узгодження показників, за якими оцінюють ПЗ розробники і користувачі. У даній роботі пропонується вирішувати цю проблему шляхом відображення тих і інших вимог на множину характеристик загальних стандартів якості [2;7].

Відображення показників якості галузевих нормативних документів і внутрішньої системи оцінки якості ПЗ на показники загальних стандартів - це співвіднесення вимог користувача $\mathrm{i}$ вимог розробника на множині показників якості загальних стандартів. Іншими словами, необхідно знайти узгодження множин показників якості користувачів і розробників на множині уніфікованих показників загальних стандартів якості ПЗ, а для тих показників, що не потрапили в результуючу множину, можна використати деякі відомі методи узгодження, наприклад, метод SQFD [15].

Але, якщо які-небудь показники галузевих стандартів і нормативних документів не відповідають загальним стандартам, то з метою повноти відображення слід здійснити пошук в інших стандартах якості ПЗ. Це потрібно виконати хоча б тому, що необхідно максимально зблизити позицію замовника з вимогами сторони, що проводить сертифікаційні випробування. Приклад відображення показників якості показано на рис. 3.

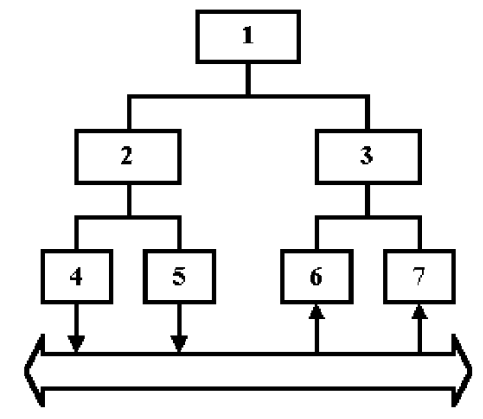

Рис. 3. Відображення показників якості галузевих стандартів на множину характеристик загальних стандартів якості ПЗ:

1 - стандарти якості ПЗ; 2 - галузеві стандарти та нормативні документи; 3 - загальні стандарти якості ПЗ; 4 - ДСТУ 3275-95 [9]; 5 - програма перевірки відповідності ПЗ контролю польотів; 6 - ДСТУ 2850-94 [2]; 7 ISO/IEC 9126-1 (2001) [7]

Подібний підхід пропонується застосовувати для будь-яких АСК розглянутого класу критичних систем.

\section{Принципи побудови моделі якості}

Згідно з моделлю якості, що запропонована в стандарті [7], маємо шість характеристик якості, які містять 27 підхарактеристик. Якщо будувати тотальну модель якості, яка вміщяє в себе усі характеристики й підхарактеристики, то одержимо не менш ніж 30 показників (кожний зі своєю метрикою). Така необгрунтовано перевантажена модель потребує впровадження трудомісткої і витратної процедури по перевірці показників. 
Для звуження множини показників, що перевіряються, пропонується із стандарту якості [7] вибрати ті базові показники якості, що безпосередньо відбивають якість функціонування програмної системи в зв'язку з ії призначенням (функціональність, надійність).

Базові показники якості характеризують ступінь виконання функцій, відповідних галузевим вимогам до ПЗ критичних систем цільового призначення [13], до яких відноситься клас АСК. Висока питома вага цих показників забезпечить готовність ПЗ до виконання очікуваних від нього дій в процесі експлуатації.

Під час оцінювання якості розглядуваних систем отримуємо групу характеристик якості, неоднорідних за своєю природою. Із цієї множини завжди можна виділити підмножину, яка містить показники якості, безпосередньо впливають на оцінку функціонування об'єкта контролю. Такі показники будемо вважати критичними, а інші другорядними.

Критичні показники мають вирішальну вагу для оцінки безпеки життєдіяльності об'єкта контролю.

Другорядні показники не впливають на оцінку стану об'єкта контролю, доки їх, у разі потреби, не вносять до базових функціональних характеристик.

Критичні показники, що названі автором за аналогією 3 назвою відповідних систем, пов'язані з оцінкою функціонування об'єкта контролю i тому мають вирішальний вплив на якість критичних систем.

Для ПЗ АСК обов'язковими характеристиками якості пропонується вважати такі:

- функціональність;

- надійність;

- зручність використання;

- супроводжуваність;

- переносимість;

- раціональність до моделі не вносимо, оскільки ця характеристика не впливає на здатність системи до контролю;

- підхарактеристики, функціональна повнота і точність є критичними, а інтероперабельність не критична, оскільки вона не впливає на оцінку функціонування об'єкта контролю. Захищеність можна опустити через те, що критичні системи працюють у сеансі з операторами, а не 3 користувачами. Узгодженість функціональності з галузевими вимогами та вимогами користувача проводиться в обов'язковому порядку шляхом відображення показників.

Безвідмовність - критична підхарактеристика надійності, а стійкість до відмов і відновлюваність можуть бути як критичними, так і ні. Це залежить від того, де використовується АСК: в ре- жимі реального часу чи після функціонування об'єкта контролю. В останньому випадку ці підхарактеристики не обов'язково вносити до моделі якості.

Придатність до вивчення і зручність інтерфейсу $\epsilon$ другорядними підхарактеристиками зручності використання, хоча інколи їх можна переводити до критичних. Узгодженість зручності використання $\epsilon$ критичною підхарактеристикою, бо потребує погодженості з цільовими вимогами користувача до ПЗ.

Змінюваність - критична підхарактеристика супроводжуваності, бо змінюваність коду не повинна впливати на якість функціонування ПЗ у цілому.

Адаптованість і налагоджуваність $є$ другорядними підхарактеристиками переносимості.

Якщо отримані фактичні значення базових показників якості відповідають нормативним вимогам, то подальшу оцінку можна провести використовуючи інтегральний показник якості, в якому вага критичних показників повинна бути оцінена на порядок більше ваги другорядних.

Інтегральний показник якості можна застосувати для вибору кращого ПЗ з декількох конкуруючих за умови врахування важливості критичних характеристик, вимоги до яких повинні виконуватися обов'язково.

Диференціальний метод [2;14] не може забезпечити одержання інтегральної оцінки якості ПЗ. Тому пропонується вибрати згідно зі стандартами $[2 ; 7]$ комплексний метод оцінки рівня якості, заснований на використанні узагальненого показника якості з рангуванням ступеня задоволення вимоги.

Запропонований метод оцінки рівняння якості ПЗ $є$ універсальним для систем даного класу. Для оцінки якості ПЗ пропонується використати узагальнений показник якості:

$$
U=\sum_{i=1}^{N} Q_{i} M_{i},
$$

де $Q_{i}$ - відносний показник якості: $Q_{i}=P_{i} / P_{i b}$, $P_{i}$ - рівень якості $i$-го елемента показника якості $(i=\overline{1, N}) ; P_{i b}-$ базове значення $i$-го елемента, $M_{i}$ - ваговий коефіцієнт (параметр значущості) $i$-го елемента показника якості.

Параметр значущості кожного критичного показника пропонуємо задавати більшим ніж сума вагових коефіцієнтів усіх другорядних показників.

Базове значення $P_{i b}$ беремо за одиницю для всіх показників, а рівень якості $P_{i}$ остаточно оцінюємо відповідно до класифікаційної метрики, 
тобто рівень елемента може дорівнювати нулеві (властивості немає) чи одиниці (властивість $\epsilon$ ).

Для розрахунку чотирирівневого узагальненого показника якості необхідно врахувати вираз (1) i ДСТУ 2850-94 [2, формула (5)]. Тоді одержимо:

$$
U_{q}=\sum_{k=1}^{K} M_{k} \sum_{i k=1}^{I_{k}} M_{i k} \sum_{j i k=1}^{J_{i k}} M_{j i k} \sum_{l j i k=1}^{L_{j i k}} M_{l j i k} Q_{l j i k},
$$

де $K$ - кількість характеристик, $I_{k}$ - кількість підхарактеристик, $J_{i k}-$ кількість атрибутів підхарактеристик; $L_{j i k}-$ кількість елементів атрибутів підхарактеристик.

Для розрахунку рівня якості пропонується обрати об'єктивні метрики, оскільки вони рахункові, і номінальні (класифікаційні) [2; 8; 14; 15].

Номінальні метрики обрані тому, що при оцінці критичних показників важлива наявність даної властивості (одиниця - виконується очікувана функція) чи ії відсутність (нуль - функція не виконується). У цьому випадку важливо фіксувати повне чи задовільне виконання.

Часткове виконання атрибута прирівнюється до невиконання, а тому для остаточної оцінки недоцільно застосування абсолютних чи відносних шкал. Після визначення наявності властивості рекомендується множити критичні показники на обрані вагові коефіцієнти.

У даній роботі пропонується використати зовнішні метрики, оскільки їх можна одержати за допомогою тестування на стадії сертифікаційних випробувань.

Внутрішніми метриками можуть вимірятися документованість, а також деякі інші важливі характеристики ПЗ, наприклад, показники точності, які отримуються за допомогою розрахункового метода і порівнюються із значеннями, одержаними 3 використанням заздалегідь побудованої моделі.

Формування моделі якості і набору критичних показників пропонується здійснювати таким чином:

- узгодження показників галузевих стандартів і нормативних документів та відображення їх на множину уніфікованих показників якості загальних стандартів;

- доповнення отриманої множини обов'язковими характеристиками якості загальних стандартів, що не ввійшли до відображення;

- вибір $з$ отриманої множини (побудованої моделі якості) тих характеристик, що пов'язані 3 оцінкою функціонування об'єкта.

Побудована процедура не рекомендує внесення в модель якості всіх показників, установлених стандартом [7]. Навпаки, експертам із лабораторії сертифікації рекомендується, враховуючи ем- піричні критерії, розумно обмежити кількість характеристик і підхарактеристик якості при побудові моделі, не погіршуючи, однак, застосовності моделі й точності оцінки. Не слід, також, вважати всі підхарактеристики критичними.

Урешті, з метою деталізації моделі необхідно визначити атрибути підхарактеристик.

Атрибути й елементи атрибутів пропонується спочатку вибирати з галузевих стандартів і нормативних документів, а для підхарактеристик, що залишаться - із загальних стандартів якості, оскільки галузеві документи задають базові вимоги до контролю об’єкта.

Якщо галузевих нормативних документів немає, то атрибути вибирають експерти із лабораторії сертифікації.

Розраховуючи рівень якості, перевагу слід віддати номінальним метрикам оцінки атрибутів із використанням вагових коефіцієнтів для рангування.

Однак для попередньої оцінки можна користатися будь-якими метриками, зокрема, тими, що використовують абсолютні чи відносні шкали.

У процесі попередньої оцінки необхідно зафіксувати досягнення мінімального задовільного рівня якості по кожному атрибуті i, тим самим, класифікувати наявність даної властивості.

Загальний рівень якості пропонується оцінювати в балах.

Уведене поняття критичних показників якості допомагає остаточно вирішити проблему побудови узагальненої моделі якості, оскільки ПЗ АСК для заданої області функціонування об'єкта контролю повинне, принаймні, мати набір критичних властивостей, які обов'язково мають бути в побудованій моделі.

Крім того, запропонований спосіб оцінки критичних показників усуває проблему неоднорідності характеристик якості, оскільки кожен атрибут якості пропонується оцінювати в три етапи:

- досягнення мінімальної задовільної планки рівня якості;

- класифікація наявності властивості;

- застосування вагових коефіціснтів.

При цьому на першому етапі можуть застосовуватися різні шкали і способи розрахунку метрик, а на другому етапі повинна використовуватися тільки номінальна метрика.

Упровадження третього етапу дозволяє зробити критичні показники незалежними від інших, оскільки ваговий коефіцієнт кожного критичного показника пропонується задавати таким, щоб він перевершував суму балів усіх другорядних елементів атрибутів з моделі якості. 


\section{Висновки}

Для побудови цільової моделі якості одного 3 класів критичних програмних систем - ПЗ АСК одержана ефективна процедура.

Процес сертифікації є трудомісткою і витратною процедурою, а тому в подальших дослідженнях необхідно розробити технологію сертифікаційних випробувань для визначення фактичних показників якості.

\section{Список літератури}

1. ДСТУ 2462-94. Сертифікація. Основні поняття. Терміни та визначення. - Чинний від 01.01.95. - К.: Дежстандарт України, 1994. - 27 с.

2. ДСТУ 2850-94. Програмні засоби ЕОМ. Показники та методи оцінювання якості. - Чинний від 01.01.96. - К.: Дежстандарт України, 1994. - 20 с. 3. ДСТУ 2853-94. Програмні засоби ЕОМ. Підготовлення і проведення випробувань. - Чинний від 01.01.96. - К.: Дежстандарт України, 1994. -17 с. 4. ДСТУ ISO 9001-2001. Системи управління якістю. Вимоги. (ISO 9001:2000). - Чинний від 27.06.01. - К.: Дежстандарт України, 2001. -23 с. 5. ISO/IEC 9126. Information Technology - Software product evaluation. - Quality characteristics and guidelines for their use, 1991. $-14 \mathrm{p}$.

6. ISO/IEC 14598-1. Information Technology - Software product evaluation. - P. 1. General overview, 1999. -20 p.

\section{И.Е. Райчев}

Проблемы сертификации программного обеспечения автоматизированных систем контроля

Рассмотрены вопросы построения процедуры сертификации программного обеспечения систем контроля как одного из классов критических программных систем, для которых сертификация соответствия является обязательной. Разработаны методы формализации процедуры формирования критериев качества и построена обобщенная модель качества программного обеспечения. Создание таких методов дает возможность повысить эффективность и качество испытаний, а потому уменьшает трудоемкость этой операции и увеличивает достоверность результатов сертификации соответствия.

\section{I.E. Raichev}

The problems of certification procedure of the software of automated systems of monitoring

In the article the problems of construction of a procedure of certification of a software of automated systems of monitoring are considered, as one from classes of the critical program systems, for which the certification of the correspondence is a mandatory procedure. The methods of formalization of a procedure of shaping of criterions of quality are developed and the generalized model of quality of a software is constructed. The creation of such methods and means enables to increase efficiency and quality of tests, that is why reduces labour input of this operation and increases reliability of outcomes of certification of the correspondence.
7. ISO/IEC 9126-1. Software engineering - Product quality. - P. 1. Quality model, 2001. -26 p.

8. ISO/IEC TR 9126-2. Software engineering Product quality. - P. 2. External metrics, 2003. -86 p.

9. ДСТУ 3275-95. Системи автоматизованого оброблення польотної інформації наземні. Загальні вимоги. - К.: Дежстандарт України, 1996. - 7c. стандарты разработки программного обеспечения // Корпоративные системы. - 2000. - № 1. 11. Калянов Г.Н. CASE-технологии. Консалтинг в автоматизации бизнес-процессов. - М.: Горячая 12. Воас Д. Процесс сертификации программ на базе информации об их использовании // Откры13. Соммервилл И. Инженерия программного обеспечения / Пер. с англ. - М.: Издательский 14. Бабенко Л.П., Лаврищева К.М. Основи програмної інженерії: Навч. посіб. - К.: Т-во "Знан15. Андон Ф.И., Коваль Г.И., Коротун Т.М., Суслов В.Ю. Основы инженерии качества программных систем. - К.: Академпериодика, 2002. - 504 с.

Стаття надійшла до редакції 25.02.04. 